\title{
Enterprises Dealing with Corruption: A Microeconomic Analysis.
}

\author{
Ermira Hoxha Kalaj, Ph.D. \\ Aleksander Moisiu University \\ ermirahoxha@uamd.edu.al
}

\begin{abstract}
This study focuses on survey data and qualitative evidence from Albanian manufacturing firms to examine the scale and consequences of corruption and bribery at the enterprise level. It analyses the costs and benefits from the entrepreneur's perspective. The set of covariates includes information about; use of external finance, policy influence, experience of corruption, firms size and ownership structure. To control for differences in the availability of collateral, the proportion of the fixed assets is included. The models used in the paper are probit where the dependent variable is binary and ordered probit where the dependent variable is categorical and orderable. Empirical results show that manufacturing firms operating in an environment in which tax evasion is more prevalent are more likely to suffer demands for bribes from corrupt officials. The regression analysis shows that tax evasion is a matter of degree and that is not limited to small and medium-sized enterprises. Even quite large firms acknowledge concealing part of their sales from tax authorities. Enterprises that are evading taxes are less likely to obtain an external audit. In addition, the data predict that corruption and tax evasion is more likely to occur when the principal owner is male rather than female. Moreover, findings show that the main effect of the separation of ownership on the likelihood of bribery is insignificant.
\end{abstract}

Keywords: corruption, bribery, ordered profit

\section{Introduction}

The lack of efficiency associated with government intervention and corruption in many developing countries are well known. Corruption may affect the extent of competition. Corruption can be described as an action in which the public power is used for personal gain (Jain, 2001). From the definition it is clear that there are three conditions necessary for the corruption to arise: discretionary power, economic rents, and weak institutions.

In contexts of weak states and underdeveloped civil societies firms may exert influence on the state. Such influence may have impact on the direction of reforms and on the quality of governance in transition countries. The way firms interact with the state has an important implication in understanding the dynamics of corruption. Studies on the phenomenon recognize different forms of it, ranging from grand to petty corruption.

This paper analyses corruption with particular focus on identifying the nature of the phenomenon. Corruption is related with the country's economic, cultural and political institutions (Svensson, 2005). According to the literature at least two relevant categories of public corruption exist: the political and administrative corruption (Bardhan, 1997; Warren, 2004). Administrative corruption refers to the petty forms of bribery related with the implementation of the the laws and regulations. Whereas the political corruption refers to the capacity of firms to influence the formation of the laws, reguations, and decrees.

\section{Literature review}

Using data for about 4000 firms in 25 transition economies, Campos and Giovannoni (2007) examine the relationship between lobbying and corruption. Their results show that lobbying and corruption are substitutes; firm size, age, owerneship, per capita GDP and political stability are important determinants of lobby memebership; and lobbying appears a much more effective instrument of political influence than corruption. However, the study does not address completely how the different kinds of corruption and lobbying interact with each other. 
Ramdani and Witteloostuijn (2012) predict that bribery is more likely to occur when the principal-owner is male rather than female. Using the World Bank Enterprise Surveys of 2002-2005 they found that the equity share of the largest shareholder is negatively related with the likelihood of firm bribery. Their finding indicate that corporations without separation of ownership and control are more likely to engage in brirery than their conterparts with separation of ownership.

Using World Bank Institute (WBI) surveys of public officials in eight Latin American dhe African countries, Recanatini et al. (2005) found that agencies whose head is popularly elected are systematically more corrupt, while independent agencies whose head is appointed by a political body tend to have better organizational design. According to their study, corruption is lower when internal decisions on budget, procurement and personnel are regularly audited. The data showed that corruption is also influenced by demand-side factors, agencies that provide services to firms are more prone to corruption.

Bitzenis and Nito (2005) conducted an empirical research to investigate the various obstacles that Albanian entrepreneurs encountered in their local business environment. Their study showed that the most important obstacles the entrepreneurs encountered in Albania included unfair competition, changes in the taxation procedures, energy crises, and lack of financial resources. In the paper bureaucracy and corruption do not appear to represent significant barriers to entrepreneurs.

Corruption and tax evasion matters because it has consequences for resource allocations (Kenyon, 2008). Tax evading firms draw labor away from those that do pay taxes. Tax evasion and corruption lowers state capacity to raise revenues and provide necessary public services. These consequences can undermine the social contract that exists between the state and the economic actors. This is of particular interest to a country like Albania. In my study I try to better understand the dynamics of tax evasion and corruption in the firm level using cross-sectional data.

\section{Data and methodology}

The Albanian 2013 Business Environment and Enterprise Performance Survey (BEEPS) has been used to give answer to the hypothesis of the paper. The survey through interviews with firms in the manufacturing and services, capture business perceptions on the obstacles to enterprise growth, the relative importance of various constrains to increasing employment and productivity, and the effect of the business environment indicators that are comparable across the countries.

The data were collected in Albania between March 2013 and July 2013 as part of the fifth round of the BEEPS, a joint initiative of the World Bank and the European Bank of Reconstruction and Development. The sample was selected using stratified random sampling. Three levels of stratification were used in Albania; industry, establishment size, and region. Industry stratification was designed as follows; manufacturing industry, and two service industries (retail and other services). Size stratification was defined; small (5 to 19 employees), medium (20 to 99 employees), and large (more than 99 employees). The number of employees was defined on the basis of the reported permanent full-time workers. Regional stratification was defined in 4 regions; Durres and Shkoder, Elbasan and Korce, Fier and Vlore, and Tirana as shown in table 1. 
Table 1- BEEPS Sample Frame

\begin{tabular}{|l|l|rrr|r|}
\hline Region & Employees & Manufacturing & Retail & $\begin{array}{c}\text { Other } \\
\text { Services }\end{array}$ & Grand Total \\
\hline Durres \& Shkoder & $5-19$ & 26 & 25 & 59 & 110 \\
& $20-99$ & 14 & 7 & 16 & $\mathbf{3 7}$ \\
& $100+$ & 8 & 0 & 0 & $\mathbf{8}$ \\
\hline & Total & $\mathbf{4 8}$ & $\mathbf{3 2}$ & $\mathbf{7 5}$ & $\mathbf{1 5 5}$ \\
\hline Elbasan \& Korce & $5-19$ & 32 & 11 & 95 & $\mathbf{1 3 8}$ \\
& $20-99$ & 8 & 0 & 5 & 13 \\
& $100+$ & 1 & 0 & 0 & $\mathbf{1}$ \\
\hline & Total & $\mathbf{4 1}$ & $\mathbf{1 1}$ & $\mathbf{1 0 0}$ & $\mathbf{1 5 2}$ \\
\hline Fier \& Vlore & $5-19$ & 20 & 9 & 50 & $\mathbf{7 9}$ \\
& $20-99$ & 14 & 0 & 4 & 18 \\
& $100+$ & 2 & 0 & 2 & 4 \\
\hline & Total & $\mathbf{3 6}$ & $\mathbf{9}$ & $\mathbf{5 6}$ & $\mathbf{1 0 1}$ \\
\hline Tirana & $5-19$ & 197 & 107 & 253 & $\mathbf{5 5 7}$ \\
& $20-99$ & 55 & 20 & 45 & $\mathbf{1 2 0}$ \\
& $100+$ & 11 & 0 & 5 & 16 \\
\hline & Total & $\mathbf{2 6 3}$ & $\mathbf{1 2 7}$ & $\mathbf{3 0 3}$ & $\mathbf{6 9 3}$ \\
\hline Grand Total & & $\mathbf{3 8 8}$ & $\mathbf{1 7 9}$ & $\mathbf{5 3 4}$ & $\mathbf{1 1 0 1}$ \\
\hline
\end{tabular}

Source: Albanian 2013 Implementation Report (World Bank, 2013)

The BEEP surveys have an excellent set of questions tax compliance, corruption levels (as reflected in gift payments to officials), the fairness of the legal system, the structure of the firms, and expectations of audits. The data set is used to estimate models about; (a) the perceived share of income reported by firms for tax purposes; (b) gift payments to tax collectors; and (c) their behaviour about tax compliance.

As a measure of bribe payments the variable, Corruption is constructed using firms responses of the question -"It is said that establishments are sometimes required to make gifts or informal payments to public officials to "get things done" with regards to customs, taxes, licenses, regulations, services etc. On average, what percentage of total annual sales, do establishment like this pay in informal payment". The variable, Tax evasion is constructed using firms responses of the question -"Recognizing the difficulties many enterprises face in fully complying with taxes and regulations, what percentage of total sales would you estimate the typical establishment in your area of activity reports for tax purposes?"1

To give answer to the hypothesis I used OLS estimation where the dependent variables are continues, probit where the dependent variable is binary and ordered probit where the dependent variable is categorical.

\section{Empirical results}

The regression results rely on the information describing 360 manufacturing firms. Table 2 show the OLS regression results relative to the corruption as the percentage of gifts or informal payments and tax evasion as percentage of sales reported for tax purposes.

\footnotetext{
${ }^{1}$ Since informal firms often misreport taxes, economics literature on informality uses this variable as a measure of the extent of unofficial activity.
} 
Table 2 - OLS Regression Results on Corruption and Tax Evasion

\begin{tabular}{|c|c|c|}
\hline & $\begin{array}{l}\text { Corruption } \\
\text { (informal payments as \% of sales) }\end{array}$ & $\begin{array}{l}\text { Tax evasion } \\
\text { (as \% of sales reported for tax purposes) }\end{array}$ \\
\hline Small $(<20)$ & $\begin{array}{l}.302 \\
(.121)\end{array}$ & $\begin{array}{l}2.014 \\
(1.35)\end{array}$ \\
\hline Medium (20-99) & $\begin{array}{l}.128 \\
(.123)\end{array}$ & $\begin{array}{l}1.104 \\
(1.24)\end{array}$ \\
\hline Large $(>100)$ & $\begin{array}{l}-.005 \\
(.129)\end{array}$ & $\begin{array}{l}.002 \\
(0.75)\end{array}$ \\
\hline Female owner & $\begin{array}{l}-.099 \\
\quad(.025)^{\star \star \star}\end{array}$ & $\begin{array}{l}.006 \\
(0.65)\end{array}$ \\
\hline External audit & $\begin{array}{l}-.478 \\
(1.75)^{*}\end{array}$ & $\begin{array}{l}-.005 \\
(6.86)^{\star * *}\end{array}$ \\
\hline Sole proprietorship & $\begin{array}{l}.026 \\
(3.21)^{\star * *}\end{array}$ & $\begin{array}{l}1.106 \\
(1.22)\end{array}$ \\
\hline Partnership & $\begin{array}{l}.005 \\
(2.80)^{\star * \star}\end{array}$ & $\begin{array}{l}.007 \\
(2.34)^{\star * *}\end{array}$ \\
\hline Corporation & $\begin{array}{l}-.046 \\
(1.63)\end{array}$ & $\begin{array}{l}.112 \\
(0.95)\end{array}$ \\
\hline Foreign ownership & $\begin{array}{l}.003 \\
(0.62)\end{array}$ & $\begin{array}{l}-.187 \\
(1.07)\end{array}$ \\
\hline Borrowed from banks & $\begin{array}{l}.039 \\
(2.81)^{\star \star \star}\end{array}$ & $\begin{array}{l}.071 \\
(2.73)^{\star \star \star}\end{array}$ \\
\hline Exporter & $\begin{array}{l}.012 \\
(4.43)^{\star *}\end{array}$ & $\begin{array}{l}.001 \\
(0.44)\end{array}$ \\
\hline Tax evasion & $\begin{array}{l}.044 \\
(1.52)\end{array}$ & - \\
\hline Cons & $\begin{array}{l}-.439 \\
(.524)\end{array}$ & $\begin{array}{l}5.12 \\
(4.43)\end{array}$ \\
\hline \# Firms & 360 & 360 \\
\hline$R^{2}$ & 0.38 & 0.42 \\
\hline
\end{tabular}

Note: ${ }^{* * *},{ }^{* *}$, and ${ }^{*}$ indicate statistical significance, respectively at the 1,5 and 10 per cent level, or better.

Besides others the link between tax evasion and corruption or bribe payments is interesting as shown in the first column, table 2. Regression results show that larger the percentage of sales paid out as bribes, the larger the tax evasion. An increase of 1 percent in tax evasion results in around 4.4 percent in corruption or bribe payments.

Larger firms, female ownership, and the presence of external audit lower the percentage of corruption in terms of gifts or informal payments. The marginal effect for corporations is higher in magnitude though the coefficient is not statistically significant. 
Corruption and tax evasion increases in the case of firms whose working capital is financed from banks. Exporting firms are subjects to corruption and tax evasion and coefficients are statistically significant. This fact may be related with the request for gift of informal payments when applying for several operating licenses.

Table 3 - Regression Results on the Requested Payments and Policy Influence

\begin{tabular}{|c|c|c|}
\hline & Informal Payment & Policy Influence \\
\hline & requested & \\
\hline & (1) & (2) \\
\hline Small $(<20)$ & .221 & .014 \\
\hline & $(.023)^{\star \star \star}$ & $(1.35)$ \\
\hline Medium (20-99) & .587 & .104 \\
\hline & $(.087)^{\star \star *}$ & $(1.24)$ \\
\hline Large $(>100)$ & .499 & -.034 \\
\hline & $(.140)^{* * *}$ & $(0.28)$ \\
\hline Female owner & -.090 & -.035 \\
\hline & $(.019)^{\star \star \star}$ & $(0.013)^{\star \star *}$ \\
\hline External audit & -.034 & -.005 \\
\hline & $(.029)^{* *}$ & $(6.86)^{\star \star \star}$ \\
\hline Sole proprietorship & .008 & 1.106 \\
\hline & $(.003)^{\star \star}$ & $(1.22)$ \\
\hline Partnership & .068 & .007 \\
\hline & $(.013)^{\star \star \star}$ & $(2.34)^{\star \star *}$ \\
\hline Corporation & -.083 & .112 \\
\hline & $(.031)^{\star}$ & $(0.95)$ \\
\hline Foreign ownership & -.302 & .187 \\
\hline & (.121) & $(1.07)$ \\
\hline Borrowed from banks & .128 & .071 \\
\hline & $(.123)$ & $(2.73)^{\star \star \star}$ \\
\hline Exporter & .005 & .005 \\
\hline & $(.129)$ & $(0.64)$ \\
\hline Tax evasion & .814 & - \\
\hline & $(.117)^{\star * *}$ & \\
\hline Cons & -.306 & 4.12 \\
\hline & (.674) & $(3.43)$ \\
\hline \# Firms & 343 & 296 \\
\hline$R^{2}$ & 0.47 & 0.32 \\
\hline
\end{tabular}

(1) Probit regression; (2) Ordered Probit

Note: ${ }^{* * *}{ }^{* *}$, and * indicate statistical significance, respectively at the 1,5 and 10 per cent level, or better.

Empirical results in table 3 show the ordered probit when the dependent variable is the requested informal payment and the ordered probit when the dependent variable is the policy influence. Regression analysis provides us with the finding 
that firms with higher tax evasion also have less influence over regulations. These results suggest that the relationship between government officials and tax evading firms is more a type of extortion by the later than capture by the former.

\section{Conclusions and comments}

This article analyses data for manufacturing firms in Albania. Results show that tax evasion and corruption in terms of gift or informal payments is not limited to small and medium size enterprises. The positive relation between corruption and tax evasion suggest that government bribery has complex consequences. This relationship maybe explained with the fact that firms "cover" the costs of bribes by under-reporting revenues. Corrupted firms lower their economic cost of bribes bur increase the probability of altering effects in front of the competitors.

Moreover, the empirical results suggest that the in the case of corporation the corruption and the probability of paying gifts or informal payment to public official is lower. In this sense the separation of ownership lowers the likelihood of firm bribery. This result maybe related with the fact that benefits of such bribery in the case of corporations are not fully internalized by the owners. On the other hand it may be explained from the managerial reputation argument because professional managers seek to preserve their good reputation avoiding to engage in illegal acts (Clarke, 2011). This result imply that stimulating the separation of ownership may be an effective instrument in the fight against corruption.

In addition, the owner gender is important. Empirical results show that a firm with a male owner is more likely to engage in bribery and informal payments to the public officials compared to enterprises with female owner. This evidence is consistent with earlier studies on the impact of gender on corruption (Swammy et. al. 2001). The female participation in firms ownership can help to reduce firm corruption and tax evasion, implying that government authorities might consider to stimulate female enterpreneurship and ownership.

\section{References}

[1] Bardhan, P. (1997). Corruption and Development: A Review of Issues. Journal of Economic Literature (35), 1320-1346.

[2] Bitzenis, A., \& Nito, E. (2005). Obstacles to entrepreneurship in a transition business environment: the case of Albania. Journal of Small Business and Enterprise Development , 12 (4), 564 - 578.

[3] Campos, N., \& Giovannoni, F. (2007). Lobbying, Corruption, and Political Influence. Public Choice , 131 (1), 1 21.

[4] Clarke, G. R. (2011). How Petty is Petty Corruption? Evidence from Firm Surveys in Africa. World Development , 39 (7), 1122-1132.

[5] Jain, A. (2001). Corruption: A review. Journal of Economic Surveys , 15 (1), 71-121.

[6] Kenyon, T. (2008). Tax Evasion, Disclosure, and Participation in Financial Markets: Evidence from Brazilian Firms. World Development , 36 (11), 2512-2525.

[7] Qerimi, Qerim and Bruno S. Sergi (2012). "The Boundaries of a Neglected Relationship: Corruption and Economic Freedom. The Case of the Western Balkans," Problems of Economic Transition, Vol. 55, No. 2, pp. 68-97.

[8] Naghshpour, Shahdad and Bruno S. Sergi (2008). "Democracy and Economic Growth: The Experience in Southeast Europe," Transformations in Business \& Economics, Vol. 7, No. 3 (15), pp. 120-128.

[9] Ramdani, D., \& Witteloostuijn, A. (2012). The Shareholder-Manager Relationship and Its Impact on the Likelihood of Firm Bribery. Journal of Business Ethics , 108 (4), 495 - 507. 
[10] Recanatini, F., Prati, A., \& Tabellini, G. (2005). Why are some Public Agencies Less than Others? Lessons for Institutional Reform from Survey Data. Washington DC: Paper presented at the Sixth Jacques Polak Annual Research Conference.

[11] Svensson, J. (2005). Eight Questions about Corruption. Journal of Economic Perspectives, 19, 19-42.

[12] Swammy, A., Knack, S., Lee, Y., \& Azfar, O. (2001). Gender and Corruption. Journal of Development Economics, 64, 25-55.

[13] Warren, E. M. (2004). What does Corruption mena in a Democracy. American Journal of Political Science (48), 328-343. 